\title{
Allelopathy of Crotalaria juncea L. aqueous extracts on germination and initial development of maize
}

\author{
La alelopatía de extractos acuosos de Crotalaria juncea L. sobre la germinación \\ de semillas y el crecimiento inicial del maíz.
}

\author{
Claudia Tatiana Araujo da Cruz-Silva ${ }^{1 *}$, Ediane Becker Matiazzo², \\ Fábio Palczewski Pacheco ${ }^{1}$, Lúcia Helena Pereira Nóbrega ${ }^{1}$
}

\begin{abstract}
The objective of this study was to evaluate the allelopathic potential of sunn hemp extracts on germination and initial development of maize. The trials were carried out in the laboratory and greenhouse with four concentrations $(0 ; 7.5 ; 15$ and $30 \%)$ of aqueous extracts obtained by grinding and leaching. In a germination chamber, more concentrated extracts (15\% and 30\%) inhibited maize germination, while shoot length (SL) was stimulated at $7.5 \%$ concentration. Ground extract stimulated root length (RL) at all tested concentrations. Root number (RN) was inhibited at higher concentrations of leached extract and stimulated for seeds exposed to sunn hemp ground extract. In the greenhouse, the longest root length (LRL) of maize was inhibited at the highest concentration $(30 \%)$ of both extracts. The ground extract inhibited the LS in all concentrations and the $7.5 \%$ concentration stimulated the RN. It was concluded that sunn hemp extracts showed allelopathic effect on maize development, which varied according to how the extracts were obtained and concentrations used.
\end{abstract}

Key words: cover crop, secondary compounds, sunn hemp, Zea mays L.

\section{RESUMEN}

El objetivo de la ingestigación fue evaluar el potencial alelopático de los extractos de crotalaria sobre la germinación y el crecimiento inicial de maíz. Los ensayos se realizaron en el laboratorio y en el invernadero con cuatro concentraciones (0; 7,5; 15 y 30\%) para los extractos acuosos obtenidos por molienda y lixiviación. En cámara de la germinación se observó que los extractos más concentrados (15 y 30\%) inhibió la germinación de maíz y que la longitud de la parte aérea (LPA) se estimuló a una concentración de 7,5\%. Para el extracto de molienda hubo estimulación en longitud de la raíz (LR) en todas las concentraciones ensayadas. El número de raíces (NR) se inhibió a concentraciones más altas de extracto de lixiviado y estimuló para las semillas expuestas a extracto machacado de crotalaria. En invernadero, la longitud de la raíz más larga (LRL) de maíz se inhibió a la mayor concentración (30\%) de los extractos de ambas maneras obtenidos. El extracto machacado inhibió los LPA en todas las concentraciones y la concentración de 7,5\% estimuló la NR. Se concluyó que los extractos de crotalaria mostraron efecto alelopático en el desarrollo de maíz, que variaba de acuerdo a cómo se obtuvieron los extractos y concentraciones utilizadas.

Palabras clave: cultivo de la cobertura, compuestos secundario, crotalaria, Zea mays $L$.

\section{Introduction}

Allelopathy is defined as the positive or negative interference of an individual, plant or microorganism on another, whose effect is mediated by compounds derived from secondary metabolism, named allelochemicals (Rizvi \& Rizvi, 1992). Allelochemicals are released into the environment and exert interference on growth and/or development of other plants directly and indirectly, through the transformation of these substances in soil by the activity of microorganisms (Ferreira \& Aquila, 2000).

Plants produce and store a large number of secondary metabolites in their several parts (leaves, stems, roots, seeds), which are then released to the environment by leaching of organic and inorganic

1 Western Paraná State University. Campus Cascavel, Paraná, Brasil. 2069, Universitária Street - Jardim Universitário - Cascavel/ PR - Zip code: 85819-110.

2 Biologist. Paranaense University. Campus Cascavel.

* Corresponding Author: lucia.nobrega@ unioeste.br 
compounds by the action of rain, dew, volatilization, root exudation and plant residue decomposition (Almeida, 1991). According to Almeida (1991); even after the plant is dead the allelopathic substances still remain active in tissues and are released into soil. When they reach the required concentration, they can affect the development of microorganisms and plants found in soil. Some metabolites act only in the presence of others in synergism, because when isolated they do not reach the minimum required concentration to exert allelopathic effect (Almeida, 1988).

Many factors determine the toxicity of allelochemicals, such as environmental conditions, concentration, plant age and physiological state. Allelochemical production varies in quality and quantity with age, cultivar, plant organ and season (Singh et al., 2003). According to Einhellig and Leather (1988), allelochemicals are also influenced by temperature, light intensity, nutrient availability, rhizosphere microbial activity and soil composition in which the roots are located.

The largest cropped area in Brazil uses notillage system, which aids weed management by allelopathy since one of the basic requirements for the system is the presence of mulch in the form of straw. The mulch acts as an insulating layer between the atmosphere and soil. It changes the temperature and soil moisture conditions, as well as decreasing their range variation. It also releases allelochemicals that inhibit seed germination and seedling development of certain species, depending on the mulch (Almeida, 1991), while it protects the soil surface, recycles nutrients and fixes nitrogen (Teixeira et al., 2004).

The species most used as cover crops are Poaceae (grasses) and Fabaceae (legumes). Grasses produce residues with greater straw permanence and are used when the goal is to keep the soil covered. However, leguminous residues show higher quality and the best covering results. They are used to add residues to the soil (Menezes \& Leandro, 2004).

The allelopathic potential of a cover crop depends on the amount of plant residue and weeds present in the soil (Tokura \& Nóbrega, 2006). It also depends on the kinds of substances released into soil and the plants that grow there. This makes the choice of plant material to be used extremely important, since with similar amounts there are different responses among cover crops to the same plant species (Silva, 2012).
Based on the benefits that cover crops can add to a no-tillage system for plants of economic interest, some studies have investigated the development of crops such as Avena sativa and Z. mays (Schneider \& Cruz-Silva, 2012); Phaseolus vulgaris (Carvalho et al., 2012) and Glycine max (Mauli et al., 2011), developed under mulch or extracts of these cover crops as well as Z. mays (Rosa et al., 2011). According to Tokura \& Nóbrega (2006), research concerning the allelopathic potential of crops has allowed reducing the costs of agricultural yield as well as the decreasing the environmental impact caused by the uncontrolled and increasing application of pesticides.

Crotalaria juncea L. (sunn hemp) is a shrub of the Fabaceae adapted to tropical conditions. It has erect and determinate growth, fast initial development and may reach up to $3.5 \mathrm{~m}$ height. In agriculture it is usually used as green manure in sugar cane soil recoverey and as an alternative to crop rotation with grain crops (Moraes et al., 2006). It is a well known botanical species because it provides a large amount of organic matter to soil and fixes nitrogen. However, its allelopathic effects are little known by farmers. This study aimed at evaluating, in laboratory and greenhouse, the allelopathic effect of sunn hemp aqueous extracts on seed germination and initial development of maize.

\section{Material and Methods}

The trials were carried out in the Biochemistry, Botany and Plant Physiology laboratories as well as in greenhouses of Paranaense University (UNIPAR), Cascavel Campus, Paraná State. Fresh leaves of sunn hemp were collected in a private farm in the Capitão Leonidas Marques-PR municipality and used as donor plant material. The seeds were used as receivers for Agroeste 1570 hybrid maize, donated by the Cooperativa Agroindustrial (COOPAVEL) and treated with fungicide in order to reduce pathogen contamination.

In order to obtain the ground aqueous extract, fresh leaves were weighed, washed, chopped into pieces of about $1 \mathrm{~cm}^{2}$ and then ground for three minutes. The extracts were prepared with $30 \mathrm{~g}$ fresh leaves per $100 \mathrm{ml}$ distilled water. Extracts were filtered to produce $30 \%$ aqueous extract (crude extract). Dilutions ( $7.5 \%$ and $15 \%$ ) were prepared up from the crude extract; distilled water was used as the control treatment. 
The procedure and concentrations used to obtain the leachate aqueous extract were similar to those described above. The difference was that the plant material (fresh leaves) was soaked in water for a 48-hour period. All $\mathrm{pH}$ concentrations were recorded with a digital pHmeter for analysis of possible interference. Optimum $\mathrm{pH}$ values have been considered as 6 to 7 (Raven et al., 2007).

Four experiment sets were carried out: two in laboratory (in a germination chamber) and two in greenhouse. For the laboratory trials $9 \mathrm{~cm}$-diameter Petri dishes were used, with two filter paper sheets and 25 maize seeds per replication. To each dish $15 \mathrm{~mL}$ sunn hemp aqueous extract (by grinding or leaching) or distilled water was added.

Petri dishes were kept in a germination chamber at constant temperature $\left(25 \pm 2{ }^{\circ} \mathrm{C}\right)$, in dark for seven days. The germination chamber, counters and other materials were previously disinfected with $70 \%$ alcohol; Petri dishes and filter paper were autoclaved at $120{ }^{\circ} \mathrm{C}$ for 20 minutes.

All trials were conposed of four treatments $(0 \%, 7.5 \%, 15 \%, 30 \%)$ with four replications. The number of germinated seeds was counted daily to calculate the germination speed index (GSI). The final evaluation after seven days considered the variables germination percentage, root number, shoot and primary root length $(\mathrm{cm})$.

Plastic containers with a $2.5 \mathrm{~L}$ capacity were used for greenhouse trials. They were filled with humus acquired in agricultural shops, in which ten maize seeds were sown. After sowing, the first watering was with $250 \mathrm{~mL}$ sunn hemp extracts (ground or leachate), while the second application of extracts occured nine days after the first. The substrate moisture was maintained by watering when necessary. Five germinated seedlings per replicate were manually transplanted, with 20 seedlings per treatment. At 30 days the shoot and root length, numbers of leaves and roots were evaluated.

The experimental design was completely randomized. Statistical analyses were performed using JMP statistical software (Statistical System Analylis SAS Institute Inc. USA, 1989-200 4.0.0.). The data were submitted to analysis of variance (ANOVA) and treatment means comparisons used the Tukey test at 5\% probability. Germination percentage data were transformed into arcsine $\sqrt{x / 100}$.

\section{Results and Discussion}

The $\mathrm{pH}$ of aqueous extracts of sunn hemp varied from 6.0 to 7.5 , which probably did not affect maize development. According to LaynezGarsaball \& Méndez-Natera (2006) when $\mathrm{pH}$ values show little variation between control and extract concentrations, they presumably have no effect on the variables evaluated.

Maize seed germination showed significant differences for seeds submitted to extracts obtained both by grinding and by leaching sunn hemp leaves. The 15 and $30 \%$ concentrations inhibited maize germination compared to the control treatment, demonstrating the allelopathic effect (Table 1). Other studies also confirm the allelopathic effect of sunn hemp extracts. According to Teixeira et al. (2004), the shoot aqueous extract of this species also reduced Lactuca sativa $\mathrm{L}$. and Bidens pilosa $\mathrm{L}$. germination, with a lower percentage when exposed to extract compared to the control treatment. Araújo et al. (2010) found that Ipomoea grandifolia (Dammer) O'Donell was more sensitive than B. pilosa L. and Euphorbia heterophilla to the alkaloid extract effect of sunn hemp; increased extract concentration significantly delayed germination. Also, Adler \& Chase (2007) reported that a $10 \%$ extract of sunn hemp fresh leaves inhibited Lycopersicon esculentum Mill. germination three and seven days after treatment, as well as Amaranthus lividus L. after three days; after seven, ten and fourteen days it also inhibited Capsicum anпuиm $\mathrm{L}$ germination.

According to Maraschin-Silva \& Aquila (2006), allelopathic effects can vary in intensity; the allelochemical action is associated with several factors such as concentration, temperature and other environmental conditions. This behavior was observed in this study for the highest concentrations of both extracts, which inhibited maize germination.

The germination speed index (GSI) showed no significant differences for sunn hemp extract obtained by grinding. GSI reduction occurred with leached extract on maize seeds $(66.66 \%)$ at the highest concentration (30\%). A similar result was observed by Teixeira et al. (2004), who found that leguminous extracts including sunn hemp reduced the GSI for lettuce. According to Lima et al. (2007), 1:5 sunn hemp extract reduced the GSI of B. pilosa, meaning that the vigor was affected and that GSI reduction promoted an increase in the day number for germination. Fontanetti et al. (2007) pointed out 
Table 1. Allelopathic effect of ground and leached aqueous extract of Crotalaria juncea $\mathrm{L}$. fresh leaves on germination $(\mathrm{G})$, germination speed index (GSI), shoot length (SL), root length (RL) and adventitious root number (ARN) of maize seedlings in germination chamber.

\begin{tabular}{|c|c|c|c|c|c|}
\hline Extract $(\%)$ & $\mathrm{G}(\%)$ & GSI (days) & $\mathrm{SL}(\mathrm{cm})$ & $\mathrm{RL}(\mathrm{cm})$ & ARN \\
\hline \multicolumn{6}{|c|}{ Ground aqueous extract } \\
\hline 0 & $57 \mathrm{a}$ & $3.6 \mathrm{a}$ & $4.8 \mathrm{~b}$ & $1.2 \mathrm{~d}$ & $2.0 \mathrm{~b}$ \\
\hline 7.5 & $49 \mathrm{ab}$ & $3.5 \mathrm{a}$ & $6.7 \mathrm{a}$ & $3.0 \mathrm{~b}$ & $3.7 \mathrm{a}$ \\
\hline 15 & $25 \mathrm{~b}$ & $3.3 \mathrm{a}$ & $3.9 \mathrm{~b}$ & $4.4 \mathrm{a}$ & $3.7 \mathrm{a}$ \\
\hline 30 & $37 \mathrm{~b}$ & $3.0 \mathrm{a}$ & $3.8 \mathrm{~b}$ & $2.3 \mathrm{c}$ & $4.1 \mathrm{a}$ \\
\hline \multicolumn{6}{|c|}{ Leached aqueous extract } \\
\hline 0 & $51 \mathrm{a}$ & $3.0 \mathrm{a}$ & $5.2 \mathrm{~b}$ & $1.7 \mathrm{a}$ & $3.5 \mathrm{a}$ \\
\hline 7.5 & $48 \mathrm{a}$ & $2.33 \mathrm{ab}$ & $6.5 \mathrm{a}$ & $1.8 \mathrm{a}$ & $3.9 \mathrm{a}$ \\
\hline 15 & $28 \mathrm{~b}$ & $1.6 \mathrm{ab}$ & $4.8 \mathrm{~b}$ & $1.4 \mathrm{a}$ & $2.4 \mathrm{~b}$ \\
\hline 30 & $17 \mathrm{~b}$ & $1.0 \mathrm{~b}$ & $3.6 \mathrm{~b}$ & $1.5 \mathrm{a}$ & $2.5 \mathrm{~b}$ \\
\hline
\end{tabular}

Different letters in columns indicate significant differences by the Tukey test at $5 \%$ probability.

that the treatment that was applied to sunn hemp in coverage decreased the emergence rate index of Cyperus rotundus.

Significant differences were observed in maize shoot length in the seedlings submitted to ground extract as well as leachate of sunn hemp leaf extract (Table 1). There was an allelopathic effect for this variable; a $7.5 \%$ extract concentration stimulated maize seedling development by 40 and $25 \%$, respectively. For maize root length with ground extract, a $15 \%$ concentration provided longer seedling root length $(4.4 \mathrm{~cm})$; this was the extract concentration used that produced seedlings with the longest roots, statistically differing from other concentrations.

The root length of maize seedlings was not affected by the treatment with the leachate extract, while adventitious root number was significantly reduced with leachate extract at 15 and $30 \%$ concentrations (Table 1). Similarly, Carvalho et al. (2012), with another species of the same genus, did not observe any significant difference using $5 \%$ leached extract of Crotalaria anagyroides. However, when the concentration increased to $10 \%$, the extracts of sunn hemp isolated or associated with other species $(C$. juncea + Avena stringosa, C. juncea + Pennisetum glaucum) affected the root system of Phaseolus vulgaris L. negatively, reducing its length.

Fontanétti et al. (2007) reported that allelochemicals may focus on different parts of plants such as roots, stems, fruits and leaves, thus the plant part used with allelopathic effect can define its purpose. Snn hemp shoots with flowers were used in this trial preparation; there appear to be allelochemicals in these parts, since sunn hemp interfered with maize germination and growth.

In greenhouse experiments, 30 days after emergence the root length of maize seedlings was inhibited by a $30 \%$ concentration of sunn hemp ground extract. There was a significant difference compared to seedlings with concentrations of 7.5 and $15 \%$. In the leachate extract, the longest root length was also inhibited at $30 \%$ concentration compared to $7.5 \%$ concentration (Table 2). Araújo et al. (2011) tested sunn hemp aqueous extract is on different spacings and densities. The authors reported that maize root length was negatively influenced by a density of 40 plants $\mathrm{m}^{-1}$, but it was more evident with 50 plants $\mathrm{m}^{-1}$. At low density ( 25 plants $\mathrm{m}^{-1}$ ), root length hardly differed from the control treatment. According to the authors, this was probably due to the fact that the metabolite concentration produced by sunn hemp was not enough to cause interference. These data corroborate those observed in this trial at the highest concentration of the studied extracts (30\%), which induced the least root growth of maize.

Maize shoot length was inhibited at all concentrations of ground extract in relation to the control treatment, with $32 \%$ growth reduction at both 7.5 and $15 \%$ concentrations and $47.5 \%$ at $30 \%$ concentration (Table 2). Leachate extract did not influence the shoot development of maize seedlings, which may be related to the way extracts were obtained and their biochemical characteristics. Resende et al. (2003) highlighted that sunn hemp presence as green manure showed a negative allelopathic effect on Saccharum officinarum L. 
Table 2. Allelopathic effect of ground and leached aqueous extract of Crotalaria juncea L. fresh leaves on the longest root length (LRL), shoot length (SL), leaf number (LN) and root number (NR) of maize seedlings, 30 days after emergence in a greenhouse.

\begin{tabular}{|c|c|c|c|c|}
\hline Extract $(\%)$ & $\operatorname{LRL}(\mathrm{cm})$ & $\mathrm{SL}(\mathrm{cm})$ & $\mathrm{LN}$ & $\mathrm{RN}$ \\
\hline \multicolumn{5}{|c|}{ Ground aqueous extract } \\
\hline 0 & $26.2 \mathrm{ab}$ & $8.2 \mathrm{a}$ & $4.9 \mathrm{a}$ & $7.0 \mathrm{a}$ \\
\hline 7.5 & $28.6 \mathrm{a}$ & $5.5 \mathrm{~b}$ & $5.1 \mathrm{a}$ & $8.7 \mathrm{~b}$ \\
\hline 15 & $26.9 \mathrm{a}$ & $5.5 \mathrm{~b}$ & $5.2 \mathrm{a}$ & $8.3 \mathrm{ab}$ \\
\hline 30 & $19.9 \mathrm{~b}$ & $4.3 \mathrm{~b}$ & $5.2 \mathrm{a}$ & $8.0 \mathrm{ab}$ \\
\hline \multicolumn{5}{|c|}{ Leached aqueous extract } \\
\hline 0 & $28.1 \mathrm{ab}$ & $5.77 \mathrm{a}$ & $5.15 \mathrm{a}$ & $7.25 \mathrm{a}$ \\
\hline 7.5 & $31.7 \mathrm{a}$ & $6.10 \mathrm{a}$ & $4.90 \mathrm{a}$ & $7.25 \mathrm{a}$ \\
\hline 15 & $29.8 \mathrm{ab}$ & $4.92 \mathrm{a}$ & $4.90 \mathrm{a}$ & $6.45 \mathrm{a}$ \\
\hline 30 & $24.0 \mathrm{~b}$ & $4.77 \mathrm{a}$ & $4.90 \mathrm{a}$ & $7.35 \mathrm{a}$ \\
\hline
\end{tabular}

Different letters in columns indicate significant differences by the Tukey test at $5 \%$ probability.

growth. The density increase of sunn hemp resulted in a progressive reduction of weed biomass.

The extracts tested in greenhouse showed no effect for some variables, and depending on the tested concentrations, influenced others. Similar to the observed data in this trial, Tokura \& Nobrega (2005) tested the allelopathic potential of cover crop aqueous extracts (Triticum aestivum, A. stringosa, $P$. glaucum, Raphanus sativus L. and Brassica napus) and observed that the extract presence did not affect maize germination; however, it affected root and shoot growth and seedling dry weight.

There was no influence on leaf number with both extracts, and root number with leachate extract (Table 2). According to Carvalho et al. (2012), typically the seedling shoot is less responsive to the allelochemical action than the root system, which is more sensitive to its action and is directly in contact with the extract. However, root number was influenced by a $7.5 \%$ concentration of ground extract, which stimulated their development in relation to the control treatment. Araújo et al. (2011) found that $P$. vulgaris L. showed the highest susceptibility to sunn hemp extract compared to maize. According to Silva (2012), all plants produce secondary metabolites that vary in quality and quantity from species to species. The resistance or tolerance to allelochemicals is more or less specific, but some species are more sensitive than others (Ferreira \& Aquila, 2000).

According to Almeida's (1988) point of view, leachates contain organic and inorganic substances which are either toxic, harmless or stimulants. The activities of these products on soil are usually temporary, since they are subject to degradation and adsorption inactivation and conversion by microorganisms. This might explain why the allelopathic effect was not observed in most variables in the leachate extract tested in the greenhouse.

Maize seedlings were influenced by the two methods of sunn hemp aqueous extract in the evaluated concentrations. It is emphasized that the results obtained in the germination chamber were more significant and the extracts influenced all variables in at least one way. Both extracts inhibited germination at the highest concentrations (15\% and $30 \%)$ and stimulated shoot length at $7.5 \%$ concentration. The leachate extract inhibited the GSI at $30 \%$ concentration. The root length was stimulated by all concentrations of ground extract, while root number was positively influenced by ground extract and negatively by leachate extract. In the greenhouse, the ground extract showed more significant effect than the leachate extract. It also reduced the shoot length at all concentrations and stimulated root number at $7.5 \%$ concentration.

It is noteworthy that, apart from the different form of seedlings grown in a greenhouse, there are factors that can influence their development such as temperature, action of microorganisms in soil, insects and light that are controlled in germination chamber.

\section{Conclusion}

The sunn hemp extracts showed allelopathic effect on maize development, which varied according to how the extracts were obtained and concentrations used. 


\section{Literature Cited}

Adler, M.J.; Chase, C. A.

2007. Comparison of the allelopathic potential of leguminous summer cover crops: cowpea, sunn hemp and velvetbean. Hortscience, 42 (2): 289-293.

Almeida, F.S.

1988. A alelopatia e as plantas. Londrina: IAPAR, $60 \mathrm{p}$. (Circular, 53).

Almeida, F.D.S.

1991. Efeitos alelopáticos de resíduos vegetais. Pesquisa Agropecuária Brasileira, 26 (2): 221-236.

Araújo, E.O.; Espírito Santo, C.L.; Santana, C.N.

2010. Potencial alelopático de extratos vegetais de Crotalaria juncea sobre a germinação de plantas daninhas. Revista Brasileira de Agroecologia, 5 (2): 109-115.

Araújo, E.O.; Santana, C.N.; Espírito Santo, C.L.

2011. Potencial alelopático de extratos vegetais de Crotalaria juncea sobre a germinação de milho e feijão. Revista Brasileira de Agroecologia, 6 (1): 108-116.

Carvalho, W.P.; Carvalho, G.J.; Andrade, M.J.B.; Fonseca, G.;

Andrade, L.; Valaci, F.; Oliveira, D.P.

2012. Alelopatia de adubos verdes sobre feijoeiro comum (Phaseolus vulgaris L.). Revista Brasileira de Biociências, 10 (1): 86-93.

Einhellig, F.A.; Leather, G.R

1988. Potentials for explointing allelopathy to enhance crop production. Journal of Chemical Ecology, 14 (10): 1829-1844.

Ferreira, A.G.; Aquila, M.E.A.

2000. Alelopatia: uma área emergente da ecofisiologia. Revista Brasileira Fisiologia Vegetal, 12: 425-430.

Fontanétti, A.; Carvalho, G.J.; Gomes, L.A.A.; Almeida, K.; Moraes, S.R.G. ; Duarte, W.F.

2007. Efeito alelopático da adubação verde no controle de tiririca (Cyperus rotundus L.). Revista Brasileira de Agroecologia, 2 (1): 1365-1368.

Laynez-Garsaball, J.A. ; Méndez-Natera, J.R.

2006. Efectos de extractos acuosos del follaje del corocillo (Cyperus rotundus L.) sobre la germinación de semillas y el crecimiento de plántulas de ajonjolí (Sesamum indicum L.) cv. Arapatol s-15. Idesia, 24 (2): 61-75.

Lima, C.; Pereira, L.M.; Mapeli, N.C.

2007. Potencial alelopático de crotalária, feijão-de-porco e gergelim na germinação e desenvolvimento inicial de picãopreto (Bidens pilosa L.). Revista Brasileira de Agroecologia, 2 (2): 1175-1178

Maraschin-Silva, F.; Aquila, M.E.A.

2006. Potencial alelopático de espécies nativas na germinação e crescimento inicial de Lactuca sativa L. (Asteraceae). Acta Botanica Brasilica, 20 (1): 61-69.

Mauli, M.M.; Nóbrega, L.H.P.; Rosa, D.M.; Lima, G.L. \& Ralish, R.

2011. Variation on the amount of winter cover crops residues on weeds incidence and soil seed bank during an agricultural year. Brazilian Archives of Biology and Technology, 54 (4): 683-690.

Menezes, L.A.S.; Leandro, W.M.

2004. Avaliação de espécies de coberturas do solo com potencial de uso em sistema de plantio direto. Pesquisa Agropecuária Tropical, 34 (3): 173-180.

Moraes, S.R.G.; Campos, V.P.; Pozza, E.A.; Fontanétti, A.;

Carvalho, G.J.; Maximiniano, C.

2006. Influência de leguminosas no controle de fitonematóides no cultivo orgânico de alface-americana e de repolho. Fitopatologia Brasileira, 31: 188-191.

Raven, P.; Evert, R.F.; Eichhorn, S.E.

2007. Biologia vegetal. 7 ed. Rio de Janeiro: Guanabara Koogan, $856 \mathrm{p}$.

Resende , A.S.; Xavier, R.P.; Quesada, D.M.; Urquiaga, S.;

Alves, B.J.R.; Boddey, R.M.

2003. Use of green manures in increasing inputs of biologically fixed nitrogen to sugar cane. Biology and Fertility of Soils, 37 (4): 215-220.

Rizvi, S.J.N.; Rizvi, V.

1992. Allelopathy: basic and applied aspects. London: Chapman \& Hall, $480 \mathrm{p}$

Rosa, D.M.; Nóbrega, L.H.P.; Lima, G.P.; Mauli, M.M.

2011. Desempenho da cultura do milho implantada sobre resíduos culturais de leguminosas de verão em sistema plantio direto. Semina: Ciências Agrárias, 32 (4): 1287-1296.

Schneider, T.C.; Cruz-Silva, C.T.A.

2012. Potencial alelopático do nabo forrageiro (Raphanus sativus L.) sobre o desenvolvimento do milho (Zea mays L.) e aveia preta (Avena strigosa Schreb.). Revista Thêma et Scientia, 2 (1): 151-156.

Silva, P.S.S.

2012. Atuação dos aleloquímicos no organismo vegetal e formas de utilização da alelopatia na agronomia. Biotemas, 25 (3): 65-74.

Singh, H.P.; Batish, D.R.; Kohli, R.K.

2003. Allelopathic interactions and allelochemicals: New possibilities for sustainable weed management. Critical Reviews in Plant Sciences, 22 (3/4): 239-311.

Teixeira, C.M.; Araujo, J.B.S.; Carvalho, G.J.

2004. Potencial alelopático de plantas de cobertura no controle de picão-preto (Bidens pilosa L.). Ciência e Agrotecnologia, 28 (3): 691-695.

Tokura, L.K.; Nóbrega, L.H.P.

2005. Potencial alelopático de cultivos de cobertura vegetal no desenvolvimento de plântulas de milho. Acta Scientiarum Agronomy, 27 (2): 287-292.

Tokura, L.K.; Nóbrega, L.H.P.

2006. Alelopatia de cultivos de cobertura vegetal sobre plantas infestantes. Acta Scientiarum Agronomy, 28 (3): 379-384. 